\title{
Methods of fixing and circulating precedent names in Chinese cultural space
}

\author{
Nikolai Nikolaevich Voropaev*
}

Institute of Linguistics of the Russian Academy of Sciences, Department of Languages of East and Southeast Asia, researcher, candidate of Philological Sciences, bld. 1, Bolshoi Kislovsky Pereulok 1, 125009, Moscow, Russia

\begin{abstract}
The paper presents some results of the study of precedent names of a Chinese cultural space and describes the main methods of fixing and circulating precedent names (PN) in a modern Chinese discourse. According to the author, the main ways include epithets-invariants of the perception of referents of precedent names in dictionaries and textbooks, and, therefore, in the minds of the Chinese who went to school; special dictionaries and collections with images of PN referents (more often these are historical personalities) and very brief encyclopedic information about them; adapted chapters from precedent texts with headings in the form of precedent names-eventonyms in books for children and teenagers; phraseological units and set expressions of Chinese language of all types which are connected with the precedent phenomena; frame works; precedent names, precedent texts. The author believes that epithets represented by phraseological units, phraseological units as such, name variants and precedent texts can be attributed to primary basic methods. These methods show the specifics of the Chinese cultural space and serve the basis for PN preservation, fixation and translation. Special dictionaries and collections, adapted texts of chapters from classic novels with names in the form of PN eventonyms and frame works are secondary derived methods and tools that demonstrate the great demand of the Chinese linguistic and cultural community for precedent names and are based on language-saved knowledge of PN and other precedent phenomena.
\end{abstract}

\section{Introduction}

Precedent names (PN) of the Chinese cultural space are individual names and names of historical and fictional characters, events and objects of the material and spiritual culture of China and the entire global space widely known in the Chinese linguistic and cultural community that are cognitively and emotionally important for all socialized speakers of the Chinese language [1]. PN is a fixed linguistic form (originally its proper name) being a collective asset of culture as a result of an emotionally figurative perception of a unique character (historical; literary; folklore, etc.), a unique situation, a unique place, a unique animal (hero of the story; less often - known from history), etc. [5].

$\mathrm{PN}$ is one of four precedent phenomena (PP). In addition to PN the PP includes precedent texts (PT), precedent situations (PS) and precedent statements (PS). All PP are interconnected and make each other actual [3, $4,5]$.

China, like all countries with a long history and rich culture, has a large arsenal of national precedent names. The specifics of many Chinese PN in their long history and in the fact that many different kinds of set expressions, phraseological units, quotes, aphorisms and other linguistic units are associated with them. This was provoked by the long history of China, rich literary and cultural traditions, the literary centricity of Chinese society, the continuity of texts over extended periods, and the linguocentricity of Chinese culture.

What contributes to the fact that a large number of PN with a long history continue to circulate actively in the Chinese cultural space today? What methods of PN fixation and circulation attract attention?

In this respect, we tried to identify the main methods of fixing and circulating precedent names in the Chinese cultural space.

\section{Results and Discussions}

First of all it should be noted that when analyzing the precedent names of the Chinese cultural space, we identified the following 4 types: 1. precedent nameanthroponym (well-known name of a person or a humanlike creature); 2 . precedent name-eventonym (wellknown name of a historical or fictional event representing a phraseological unit, a verbal cliché or a collocation); 3 . precedent name-chrematonym (well-known individual name of a single object of the country's material culture); 4. precedent name-ideonym (well-known individual name of a single object of the country's spiritual culture) [1,2].

At the moment, we have discovered the following methods of fixing and circulating precedent names in the Chinese cultural space: 
1. Epithets-invariants of perception in dictionaries and textbooks, in the minds of the Chinese who went to school.

We believe that this is the most interesting method to fix and circulate PN in the Chinese cultural space. These stable epithets of PN referents contribute to the rapid formation and strong fixation of these invariants of perception of a PN referent and the PN itself in the memory and consciousness of Chinese speakers. As a rule, they are presented in dictionaries, textbooks and various tutorials.

A large number of PN are enshrined in the Chinese language and in the minds of Chinese speakers through such stable definition epithets. Moreover, these definitions may be quite official and recorded in special dictionaries or collections, or may be closer to the spoken language and sound in the speech of the Chinese. For example, the dictionary People of History [12] represents 121 outstanding personalities of Chinese history and is built following a thematic principle. This dictionary consists of 8 sections (politicians, military leaders, scientists, writers, famous merchants or business people, masters of the arts, philosophers, heroic personalities).

It is noteworthy that each personality in the table of contents of this dictionary is represented by a description, a brief characteristic in the form of an epithet, which is often expressed by a phraseological unit, a verbal cliché or a collocation. We believe that these descriptions should be considered as invariants of the perception of a given personality in the Chinese linguistic and cultural community; these expressions are constantly used in the descriptions of these personalities and in other sources. Let us give some examples from this dictionary (years of life in the translations are added by us):

卧薪尝胆 - 勾践 'Suffering difficulties for the sake of a great future goal (lit. lie on a brushstroke and taste bile) - Gou Jian (? - 465 BC)', 卧薪尝胆 - phraseological unit, lit. 'to rest on a brushwood and taste bile (according to the parable of the King Gou Jian of Yue, who slept on a brushwood and licked bile before eating so as not to forget about revenge to the victorious principality of $\mathrm{Wu}$ ), fig. to whip up a feeling of revenge; prepare for revenge';

千古一帝 - 秦始皇 'The first emperor since time immemorial - Qin Shihuang (259-210 BC)';

蒙古国的创建者 - 成吉思汗 'Founder of the Mongolian state - Genghis Khan (1206-1227)';

垂帘听政 - 慈禧太后 'The Empress Dowager Cixi (1835-1908) who ruled from behind the curtain'.

Based on the materials of this dictionary, we conducted a survey of the native speaker and analyzed other sources. Many epithets were confirmed in other sources, and according to some PN, other set designations were found that confirm each other and epithets from the dictionary [12]. Here are some examples of PN by Cai Lun:

造纸术的发明者一蔡伦 'Inventor of paper manufacturing technology - Cai Lun (? - 121)' - an example from the dictionary [12];
蔡伦造纸 'Cai Lun made paper' - an example from a native speaker.

PN examples by Zheng Chenggong:

民族英雄 - 郑成功 'National hero - Zheng Chenggong (1624-1662)' - an example from the dictionary [12];

郑成功收复台湾 'Zheng Chenggong returned Taiwan' - an example from a native speaker;

郑成功收复台湾 'Zheng Chenggong returned

Taiwan' - an example from a history book [23].

PN examples by Lin Zexu:

禁烟英雄 - 林则徐 'Hero who banned opium - Lin Zexu (1785-1850)' - an example from the dictionary [12];

林则徐禁烟 'Lin Zexu - banned opium' - an example from a native speaker;

虎门销烟林则徐 'The destruction of opium in Humen - Lin Zexu' - an example from a native speaker (the destruction of opium in Humen: in 1839, Li Zexu forced the British to surrender the entire batch of opium, after which he ordered its destruction, which was the reason for the First Opium War);

林则徐与虎门销烟 'Lin Zexu and the fire in Humen' - an example from a history book [23].

PN examples by Yue Fei:

抗金名将 - 岳飞'The illustrious commander who fought the Jurchen - Yue Fei (1103-1142)' - an example from the dictionary [12];

精忠报国 - 岳飞'Loyally and devotedly serving the country - Yue Fei' - an example from a native speaker;

忠心报国的岳飞 'Yue Fei faithful to the homeland' an example from the history book [23].

PN examples by Zu Chongzhi:

杰出的数学家 - - 祖冲之 'Outstanding mathematician - Zu Chongzhi (429-500)' - an example from the dictionary [12];

圆周率之父祖冲之 'The father of $\pi$, the number Pi (ratio of the circumference to its diameter) - Zu Chongzhi' - an example from a native speaker;

数学家祖冲之 'Mathematician Zu Chongzhi' - an example from the history book [23].

PN examples by Qin Shihuang:

千古一帝 - - 秦始皇 'The first emperor since time immemorial - Qin Shihuang (259-210 BC)' - an example from the dictionary [12];

中国的第一位皇帝 - 秦始皇 'The first emperor of China - Emperor Qin Shihuang' - an example from the history book [23];

统一六国秦始皇 'United six kingdoms - Qin Shihuang' - an example from a native speaker.

PN examples by Shang Yang:

政治改革家 - 商鞅 'Political reformer - Shang Yang (approximately 390-338 BC)' - an example from the dictionary [12];

商鞅变法 '(Political) reform of Shang Yang' - an example from a native speaker.

PN examples by Zheng He:

七下西洋 - 郑和 'Seven times sailing to overseas countries - Zheng He (1371-1433)' - an example from the dictionary [12]; 
郑和下西洋 'Zheng He sets sail' - an example from the history book [23].

PN examples by Lei Feng:

全心全意为人民服务 - 雷锋 'With all his heart and all his thoughts served the people - Lei Feng (1940-1962)' - an example from the dictionary [12].

This epithet completely coincides with the definition of this PN in the Chen Xianchun dictionary [24], and also coincides with the part of this definition - the verbal cliché 为人民服务 'serve the people', which is applied along with the image of Lei Feng on the ashtray and lighter, which we acquired in Beijing.

The definition of PN by Hu Xueyan from the dictionary [12] 红顶商人 - 胡雪岩 'Merchant-official Hu Xueyan (1823-1885)' completely coincides with the name of the novel dedicated to this historical personality [9].

We believe that the reason and possibility of such forms of fixation, consolidation of invariants of PN perception in the Chinese cultural space and in the consciousness of speakers of the Chinese language and culture lies in the peculiarities of the Chinese language and the traditions of language communication. Due to the flexible use of Chinese language morphemes, it is possible to form such easily memorable formula epithets.

Most likely, these trends come from the literary tradition, because often the headlines of chapters in ancient Chinese stories represent a brief description of key actions, actions of heroes. For example, some famous stories by the famous writer Feng Menglong are called 蒋 兴哥重会珍珠衫 'Jiang Xingge again sees a pearl shirt', 卖油郎独占花魁 'The oil seller conquers the Queen of Flowers', etc.

2. The second method of fixing and circulating PN in the Chinese cultural space are special dictionaries and collections with images of PN referents (more often these are historical personalities) and brief encyclopedic information about them. Entries in such dictionaries can be different in volume, for example, in the dictionary [22] the volume of the entry is from 50 to 200 characters, in the dictionary [8] the volume of the entry is about 100 characters, in the dictionary [12] the volume of the entry is about 1000 characters.

There are also special dictionaries and collections in China that are addressed to foreigners. For example, 60 $\mathrm{PN}$ and 60 precedent situations under the corresponding headings which are PN eventonyms are presented in the special dictionary for learning Chinese and the culture of foreigners [24].

Noteworthy is the collection 100 Diangu (diangu) [7], which presents 100 precedent situations of the Chinese cultural space, the names of which represent PN eventonyms. Naturally, these stories actualize a huge number of PN anthroponyms. The authors of this collection are not professional philologists or linguists, but engineers He Zeren and Zhou Lingzhong, who dearly loved and appreciated the national Chinese culture and spoke English perfectly. Already at his advanced age Mr.
He Zeren decided to make this collection with the translation into English to acquaint the foreigners learning Chinese with the Chinese culture more deeply. However, he managed to record only 20 classic diangu stories, fell ill and died. At his dying request, his cousin, Mr. Zhou Lingzhong, completed the book recording another 80 diangu (classic precedents). We believe that this fact indicates that China has a special attitude towards national traditional culture and this also contributes to the consolidation and circulation of $\mathrm{PN}$ and other precedent phenomena.

3. The next method to fix and circulate PN in the Chinese cultural space is adapted texts of chapters from classic Chinese novels with headlines in the form of precedent names-eventonyms.

Many PN circulate as part of miniature texts in textbooks, booklets about historical sights and in adapted narration texts of chapters of famous classic novels (precedent texts). Often the names of such adapted chapter texts are precedent names-eventonyms (i.e. names of precedent situations). Usually, such texts present verbalization (short retelling) of the key precedent situation of the novel. China's four famous classic novels (Three Kingdoms, Outlaws of the Marsh, Dream of the Red Chamber, and Journey to the West) are important sources of precedent names of the Chinese cultural space.

Such texts of adapted chapters from these novels are published several pieces under the cover of one book, for example, such editions as $[10,15,16,17,18,20]$. Here we meet such headlines (PN eventonyms) as, for example, from Three Kingdoms (the novel was written in the $14^{\text {th }}$ century): 曹操煮酒论英雄 'Cao Cao heats wine and discourses upon heroes', 诸葛亮草船借箭 'Zhuge Liang borrowing arrows with straw boats' [15], 望梅止渴 'quench thirst looking at plums', 乐不思蜀 'cannot remember Shu while having fun' [16].

From the novel Outlaws of the Marsh (the novel was written in the middle of the $14^{\text {th }}$ century): 鲁提辖拳打镇 关西 'Lu Zhishen kills Zhen Guanxi with his fists', 李逵 返乡路逢李鬼 ' $\mathrm{Li}$ Kui meets Li Gui on the way to the native land' [17], 武松打虎 'Wu Song beating the tiger', 倒拔垂杨柳 'Lu Zhishen uprooting a willow tree' [18].

From the novel Journey to the West (written in the $16^{\text {th }}$ century): 齐天大圣闹天宫 'Monkey King creates havoc in Heaven), 偷吃人参果惹祸 'Zhu Bajie in secret eats the magical fruit and brings misfortune' [20].

From the novel Dream of the Red Chamber (written in the $18^{\text {th }}$ century): 刘姥姥进大观园 'Granny Liu visits the Grand View gardens', 黛玉葬花抒悲情 'Lin Daiyu buries flowers and pours out sadness' [10]. And, naturally, the corresponding PN anthroponyms are constantly repeated in the texts.

We also have a collection of wonderful brochures on the novels Three Kingdoms (47 books) and Dream of the Red Chamber (19 books). Such brochures represent small 12 by $9-10 \mathrm{~cm}$ books $40-70$ pages each. Each brochure is devoted to only one precedent situation or character and has a corresponding name. For example, in the series 
based on Three Kingdoms (三国演义) there are such books as:

三顾茅庐 [14]. This unit of Chinese is a PN eventonym and a phraseological unit of the chengyu type (precedent phraseological unit). 三顾茅庐 'Liu Bei Visiting the Grass-Roof Farmhouse Three Times' (about a three-time visit of Liu Bei to Zhuge Liang; fig. to urge the help of an experienced person, to urge an invitation to serve; to bow, to persuade, to prevail upon).

空城计 [11]. This unit of Chinese is a PN eventonym and a phraseological unit of chengyu or guanyongyu type. 空城计 'the stratagem of the empty city' (Zhuge Liang, which found himself in a besieged city with a handful of soldiers in the face of a huge army, ordered the soldiers to open all the gates, take brooms and sweep the streets, and sat down on the city wall and played the lute; the enemy became suspicious and retreated; fig. bluff, psychological attack).

走麦城 [25]. This unit of the Chinese language is a PN eventonym and can formally be attributed to phraseological units such as guanyongyu. 走麦城 'leave Maicheng' (Guan Yu after the loss of Jingzhou moved to Maicheng, when leaving Maicheng, he was captured and killed by the troops of the Wu kingdom in 219 AD); fig. to be in a hopeless position; go to doom).

In the series based on the Dream of the Red Chamber (红楼梦), for example, there are such books as:

刘姥姥进大观园 [13]. This unit of Chinese is a PN eventonym (the name of an episode from the novel) and a collocation. 刘姥姥进大观园 'Granny Liu visits the Grand View gardens' (Grandmother Liu is a poor old woman having difficult life who spent her entire life in a village. Accidentally falling into a wealthy family in the city, she encountered many things that she had not seen before, which often made people laugh; fig. about a person who first saw something amazing, usually joking about his small outlook; broaden the outlook; go out to the public laughter).

王熙风 [19]. This unit of Chinese is a PN anthroponym. 王熙风 'Wang Xifeng is a character of the classic novel Dream of the Red Chamber'. (Wang Xifeng is a young beautiful young lady from a wealthy family. She is extremely intelligent, resourceful, capable, active, but at the same time she is cruel, evil and ruthless. Modern Chinese use her name to denote unkind, harsh, active, strong women).

As the native speaker informed us, when she was in the elementary school, and this was in the late 70 s of the last century, a bookseller constantly stood near the school with many such books, and the children took them for a short time for a small fee to read immediately near the book stall. Since most of the page $(90 \%)$ in such a book is occupied by a picture, and the text under the picture is only 1-3 lines, this reading did not take long. It turns out that the verbalization of precedent situations in such books is presented as some kind of comics. Such a very interesting and effective way of disseminating and circulating precedent texts and other phenomena was then typical for China.
4. The next method of fixing and circulating PN in the Chinese cultural space is phraseological units of the Chinese language.

If there is a general designation of all set phrases shuyu or 'fixed/familiar expression' (熟语), there are usually three main types of phraseological units in Chinese: chengyu, xiehouyu and guanyongyu. However, these types are distinguished purely by formal features: chengyu or 'fixed expressions' (成语) mainly represent 4 complex phraseological units usually having a source, some chengyu are not difficult to understand by hieroglyphs, and to understand the meaning of others it is necessary to study the source and a historical precedent; guanyongyu or 'common expressions' (惯用语) are usually 3 complex set phrases built according to the norms of the modern spoken language; xiehouyu are composite phraseological units (歇后语 'hinting expressions' - two-member expressions, in which the first part is an allegorism (譬喻), and the second - the disclosure of the allegorism (解答), in connection with which such speeches are often called 'reservationsallegorisms' (譬喻解答式的歇后语, lit. 'reservations in the form of allegorisms - disclosure'). In the field of Chinese phraseology there are also such designations as 格言 'aphorism', 浐语 'proverb', 俗语 'saying, popular expression', 名句 'quotation, aphorism, catchphrase, famous expression', 引用语 'quote'.

Most Chinese phraseological units keep PN up to date. Often PN anthroponyms are directly included in phraseological units.

In addition to these types of phraseological units, there are various kinds of set expressions, collocations, phrasemes-calculations, verbal clichés in Chinese, which are also often associated with PN, for example: 姜太公钧 鱼 'Lord Jiang Casting a Line', 苏武牧羊 'Su Wu Shepherding in the Wild', 岳飞枪挑小梁王 'Yue Fei Spearing the Prince of Liang', 刮骨疗毒 'Scraping the Poison off the Bone' (thus Hua Tuo cured Guan Yu), 岳 母刺字 'Mother Yue Tattooing Her Son's Back', 三打 白骨精 'The Monkey King Subduing White-Bone Demon Three Times', 穆桂英挂帅 'Mu Guiying Taking the Title of Marshal', 鲁智深倒拔垂杨柳 'Lu Zhishen Uprooting a Willow Tree', 武松打虎 'Wu Song Beating the Tiger', 荆轲刺秦 'Jing Ke's attempt on the ruler of the Qin kingdom', 四大名著 'Four Great Creations' (a fixed name for the four most famous novels of the Chinese literary tradition).

Therefore, in order to optimize the study of precedent names and other precedent phenomena (texts, statements and situations), we propose to distinguish a single category of precedent phraseology, and within its framework to study all precedent phraseological units, i.e. such phraseological units and set expressions that are connected and thus update PP regardless of their form. There is a special term diangu to denote this kind of units 
different in form, but essentially uniform in the Chinese language and culture.

Diangu (典故 lit. classic precedent) - ancient stories/plots mentioned through set expressions (phraseological units) in various types of texts and popular words or expressions from certain sources that are quoted in poetry and prose. Accordingly, there are two types of diangu in China: plot/event diangu 事典 'diangu plot/event' - diverse in form set expressions that in poetry and prose indicate a specific ancient story/plot or event. Consequently, quote/verbal diangu 语典 'diangu statement/expression' - words or expressions from specific sources quoted in poetry and prose [21]. Even many PN anthroponyms in China are considered diangu and are included in diangu dictionaries.

5. The next effective method to fix and circulate PN in the Chinese cultural space is frame works. Frame works (from the English frame 'structural unit of various intellectual and other objects') - books, films, television series and other objects of material and spiritual culture of a country, based on precedent texts or dedicated to PN referents (historical and fictional personalities and events) [1]. We propose to consider all forms of PN actualization in a discourse as frame works. Frame works include books, lectures, articles, films/television series/cartoons, plays (theatrical performances), instrumental musical works, songs, historical reconstructions, monuments, houses-museums, souvenirs, paintings, places of religious worship, twin actors, information messages (in newspapers, magazines, the Internet, television, radio, etc.) For example, the book Red Cliff (赤壁) by a modern fiction writer Shi Jiepeng (史杰鹏) was published in China in 2008 [6], and then the television series of the same name was released, which presents the precedent characters and situations of the Three Kingdoms novel, as well as historical personalities and events of the Three Kingdoms period. The name of these products of the modern film industry and literary creativity is a PN chrematonym - the name of a famous Mount Chibi (lit. red cliff). This PN is part of phraseological units (PI eventonyms) representing the names of a historical event (PS): 赤壁䴤兵 'a difficult battle at Chibi in $208 \mathrm{AD}$ (fig. to win a fierce battle; heavy battle, big battle)' (variants: 火烧赤壁, 赤壁之战, 赤壁大战).

In 2010, a new animated film Q 版刘关张 'Charming Liu Bei, Guan Yu and Zhang Fei' was produced in China. The word Q 版 in the name of the cartoon is a neologism, where the letter Q means the word 可爱 'nice; cute; charming' resembling in sound the beginning of the English word cute 'charming, appealing, attractive, a component 版 ban has the following meanings: 1. printed board; cliché; 2 . publication; version. 2009.

A biographic movie about Confucius was shot in

There are many examples of frame works and, we believe, this phenomenon also requires separate studies.

6. We believe that PN variants also contribute to the fixation and circulation of PN, for example, as we were able to find out at the moment, PN Guan Yu has six variants:
1. 关公 'Mr. Guan';

2. 关老爷 'Lord (God of War) Guan';

3. 关云长 'Guan Yunchang (his adult name)';

4. 关帝 'Guan Di, Emperor Guan (Guan Yu was canonized as a deity of war)';

5. 关大王 'Chieftain Guan';

6. 关二爷 'Second Mr. Guan (second, because in the union triad with Liu Bei and Zhang Fei, he took second place in seniority after Liu Bei)'.

PN Sun Wukong - four options: 孙行者 'traveler Sun', 孙大圣 'great wise man Sun' or 'absolutely wise Sun', 孙猴子 'monkey Sun', 齐天大圣 'Great Wiseman Equal to the Sky'.

PN Li Kui has a variant 黑旋风 'a black whirlwind', and PN Zhang Fei - 猛张飞 'daredevil Zhang Fei'.

Many PN variants emphasize certain differential features of the PN referent, affect the formation of a national invariant of the perception of the PN referent and the PN itself.

7. Well, the last method we have highlighted at the moment for fixing and circulating PN in the Chinese cultural space is the precedent texts themselves. It stands to reason that such texts are usually read in school years and this can be the most reliable basis for the entire knowledge of PN and other PP. Another thing is that after time many episodes (PS), statements and even names may be forgotten, so all the above methods are simply aimed at constantly circulating and maintaining PN in the cognitive base of the members of the linguistic and cultural community in an active state.

\section{Conclusion}

Thus, it can be concluded that due to the linguocentricity and literary centricity of the Chinese cultural space, special set expressions and names have been accumulated and preserved by the language over the centuries precedent phraseological units of diangu, which have formed a solid basis for the preservation, fixation and circulation of many-centuries long $\mathrm{PN}$, and their continuous actualization in the speech and texts of the modern members of Chinese linguistic and cultural community.

A method of forming perception invariant epithets in dictionaries, textbooks and in the consciousness of carriers in the form of phraseological units, phraseological units that update PN in a discourse, precedent names, precedent texts - these methods can be attributed to the primary basic methods of PN circulation, since these linguistic units have been formed over the centuries and many of them or their elements have become the units of language dictionaries and are actively used in a discourse and in speech.

Epithets in the form of phraseological units, phraseological units and PN variants can be considered a single block of diangu precedent phraseological units. These methods show the specifics of the Chinese cultural space and serve the basis for the preservation, fixation and translation of PN. 
Special dictionaries, collections, adapted texts of chapters from classic novels with names in the form of PN eventonyms and frame works are secondary derived methods and tools that are based on diangu units stored in the language and knowledge of PN and other precedent phenomena and demonstrate the greater need and demand of the Chinese linguistic and cultural community for precedent names, for their anchoring and circulation in a Chinese-language discourse.

The existence and creation of a huge number of frame works dedicated to PN referents shows the importance and demand of PN and all PP for public life, language communication and the cultural development of the Chinese cultural space. This demand of PN and other PP by the Chinese linguistic and cultural community suggests the need for further deeper and more systematic study of precedent names and other precedent phenomena.

\section{References}

1. N.N. Voropaev. Precedent names in a Chineselanguage discourse: dissertation of the candidate of philological sciences. (Moscow, Institute of linguistics of RAS, 2012).

2. N.N. Voropaev. China: names for the ages. Precedent characters. Linguoculturological reference dictionary for learning Chinese language, culture, history, literature. $-2^{\text {nd }}$ ed., rev. (Moscow, VKN publishing house, 2018).

3. D.B. Gudkov. Theory and practice of intercultural communication. (Moscow: ITDGK Gnosis, 2003).

4. M.L. Kovshova. Dictionary of linguoculturological terms. Compiled by M.L. Kovshova, D.B. Gudkov. Publishing editor M.L. Kovshov (Moscow: Gnosis, 2017).

5. V.V. Krasnykh, Dictionary and grammar of the culture of language; Fundamentals of psychocultural linguistics. (Moscow: Gnosis: 2016).

6. 赤壁 // 史杰鹏 著. - 桂林: 广西师范大学出版社, 2008. 297 页. [Shi Jiepeng, Red Cliff. (Guilin, 2008)].

7. 典故 100: 汉英对照/周苓仲, 何泽人编著. - 北京 : 华语教学出版社, 1998. 284 页. [Zhou Lingzhong, He Zeren, 100 diangu: parallel texts in Chinese and English Languages (Beijing, 1998)].

8. 国人必知的 2300 个中国名人 // 沈智编著. - 沈阳 ：万卷出版公司，2009. 462 页. [2300 famous Chinese whom people of our country should know. Compiled by Shen Zhi (Shenyang, 2009)].

9. 红顶商人 - - 胡雪岩 // 高阳著. 长春: 吉林文史 出版社出版, 1992. 449 页. (Wu Xueyan, Gao Yang, The Merchant-official (Changchun, Publishing house of literature and history of Jilin province, 1992)].

10. 红楼梦 / (清) 曹雪芹著（缩写本）；顾作峰主编 . - 哈尔滨: 哈尔滨出版社, 2009. 164 页. [Dream of the Red Chamber (Qin dynasty) Cao Xueqin (abbreviated edition); under the editorship of $\mathrm{Gu}$ Zuofeng (Harbin, 2009)].

11. 空城计（三国演义之三十七）/田衣改编; 徐正平 绘画. - 上海人民美术出版社, 1979. 51 页. [The stratagem of the empty city / the $37^{\text {th }}$ brochure on
Three Kingdoms, adaptation: Tian Yi (Shanghai, 1979)].

12. 历史上的那些人 // 何跃青. - 北京: 地震出版社, 2007. 243 页. [People of history. Compiled by: He Yueqing (Beijing, 2007)].

13. 刘姥姥进大观园 / 曹雪芹原著; 潘勤孟编文; 张令 涛, 胡若佛绘图. - 上海人民美术出版社, 1958. 52 页. [Granny Liu visits the Grand View Gardens / author of the original Cao Xueqin; adaptation/retelling: Pan Qinmeng; (Shanghai, 1958)].

14. 三顾茅庐（三国演义之十八）/田衣，金协中，王 星北改编; 杨青华绘画. - 上海人民美术出版社, 1979. 67 页. [Liu Bei Visiting the Grass-Roof Farmhouse Three Times / $18^{\text {th }}$ brochure on Three Kingdoms, adaptation: Tian Yi, Jin Xiezhong, Wang Xingbei (Shanghai, 1979)].

15. 三国演义 / (明) 罗贯中著 (缩写本) ; 顾作峰主 编. - 哈尔滨: 哈尔滨出版社, 2009. 164 页. [Three Kingdoms (Ming dynasty) Luo Guanzhong (abbreviated edition); under the editorship of $\mathrm{Gu}$ Zuofeng (Harbin, 2009)].

16. 三国演义/ (明) 罗贯中著; 闻仲改编. - 南京: 南京大学出版社, 2014. 200 页. [Three Kingdoms / (Ming dynasty) Luo Guanzhong; adaptation: Wen Zhong (Nanjing, 2014)].

17. 水汻传 / (明) 施耐庵著 (缩写本); 顾作峰主编 . - 哈尔滨：哈尔滨出版社, 2009. 164 页. [Outlaws of the Marsh (Ming dynasty) Shi Naian (abbreviated edition); under the editorship of $\mathrm{Gu}$ Zuofeng (Harbin, 2009)].

18. 水汻传/ (明) 施耐庵著; 闻仲改编. - 南京: 南 京大学出版社, 2014. 200 页. [Outlaws of the Marsh / (Ming dynasty) Shi Naian; adaptation: Wen Zhong (Nanjing, 2014)].

19. 王熙凤/曹雪芹原著; 潘勤孟编文; 张令涛, 胡若 佛绘图. - 上海人民美术出版社, 1958. 52 页. [Wang Xifeng, author of the original: Cao Xueqin; adaptation/retelling: Pan Qinmeng; drawings: Zhang Lingtao, Hu Ruofu (Shanghai, 1959)].

20. 西游记 / (明) 吴承恩著; 刘晓菲, 田玉晶改写. - 昆明: 云南教育出版社, 2008. 192 页. [Journey to the West / (Ming dynasty) Wu Cheng'en; adaptation/retelling: Liu Xiaofei, Tian Yujing. (Kunming, 2008)].

21. 中国典故大辞典 / 赵应铎. - 上海: 上海辞书出版 社, 2014. 1359 页. [Zhao Yingduo, Big dictionary of China's diangu (Shanghai, 2014)].

22. 中国历代名人图典 // 李典编著. - 北京: 京华出版 社, 2005. 530 页. [Famous people of the Chinese history. Dictionary with illustrations. Compiled by: Li Dian. (Beijing, 2005)].

23. 中国历史常识: 中俄对照/中华人民共和国国务院 侨务办公室, 国家汉语国际推广领导小组办公室 编. 北京: 华语教学出版社, 2006. 260 页. [Elementary knowledge of the history of China: parallel texts in Chinese and Russian languages. Compiled by the Chinese state office of leadership team on the international distribution of Chinese at 
the Office of the State Council of the People's Republic of China for the Chinese living abroad. (Beijing, 2006)]

24. 中国文化中的典型人物与事件 // 陈贤纯编著. - 北 京: 北京语言大学出版社, 2005. 339 页. [Precedent characters and events in the culture of China.
Compiled by: Chen Xianchun. (Beijing: Publishing house of Beijing University of language, 2005)]

25. 走麦城（三国演义之三十二）/吴其柔, 田衣改编; 严绍唐绘画. - 上海人民美术出版社, 1979. 71 页. [Departure from Maicheng. $32^{\text {nd }}$ brochure on Three Kingdoms, adaptation: Wu Qirou, Tian Yi (Shanghai, 1979)]. 